\title{
ANTICOMUNISMO EN EL NO-DO. La continua elaboración del enemigo
}

Encarnación BARRANQUERO TEXEIRA Universidad de Málaga ebarranquero@uma.es

\section{ANTI-COMMUNISM IN THE NO-DO. The continuous elaboration of the enemy}

Resumen: En este artículo pretendemos investigar los contenidos sonoros y las imágenes de los noticiarios que eran exhibidos antes de las películas en los cines españoles, ya que son una fuente de gran interés para el conocimiento de la propaganda, la censura y la vida cotidiana durante el franquismo y la Transición. El enemigo comunista tomaba diversas formas (sovietismo, revueltas, huelgas y hasta liberalismo) y evolucionaba a lo largo de los años, pero estuvo siempre presente, como estrategia propagandística y como expresión de la naturaleza del régimen.

Abstract: In this article we want to investigate the comments and images of the news programs that were shown before the movies in the Spanish cinemas, since they are a source of great interest for the knowledge of propaganda, censorship and daily life during the Francoism and the Transition. The communist enemy took various forms (sovietism, revolts, strikes or liberalism) and evolved over the years, but was always present, as a propaganda strategy and as an expression of the nature of the regime.

Palabras clave: NO-DO. Franquismo. Anticomunismo. Propaganda. Cine

Francoism. Anti-Communism. Propaganda. Cinema 


\section{Introducción}

El NO-DO, una de las estrategias propagandísticas más importantes del régimen franquista, ha venido siendo estudiado desde diferentes puntos de vista, sobre todo por las técnicas de imagen y el tratamiento de la comunicación (Sánchez-Biosca y Tranche, 1993), los estudios antropológicos o históricos, ya sean eligiendo el tratamiento del noticiario de ciertos lugares y regiones (Roll Grande, 2011; De Marco, 2013; García, 2015), bien períodos (Ardanaz, 1998), o temas concretos (Paz y Coronado, 2005; Gil y Gómez, 2014; Rodríguez, 2005). Efectivamente, estos noticieros que se emitían antes de proyectar las películas constituyen un conjunto que forma parte de la cultura, la memoria y la vida cotidiana del franquismo y la Transición.

Su importancia viene dada, no tanto por los conocimientos que podían aportar estos noticieros y documentales sino por el tratamiento político de estos contenidos y por la elección de los temas que, dadas las coyunturas políticas y sociales, dados los intereses de la mayoría de la población, llegaban a rozar el absurdo. Creemos que los temas que no eran tratados y los elegidos son tan reveladores como la manipulación ideológica que desplegaban en prácticamente todos, con el matiz derivado del contexto histórico en que se elaboraron y se lanzaron sobre una población que quería entretenerse, pasar el tiempo o divertirse en unos años destacadamente difíciles para una mayoría.

Para los historiadores son un retrato de lo que el régimen quería que fuera España y el mundo y hasta en esa necesidad de los especialistas a la hora de enfrentarse a la documentación escrita de esta etapa tan reciente de nuestra historia, de leer entre líneas, releer o pararse en un detalle -un fotograma-, constituyen una fuente de indudable interés, incluso una fuente sin la que no se puede entender la formación -o deformación- política, los intereses, la interpretación del franquismo y sus años posteriores, así como una contribución a la formación de la opinión de la población.

El enemigo rojo es representado conscientemente mediante una serie de recursos que destacaremos, aunque también está presente en ciertos reportajes en un segundo plano o visible mediante un juego de imágenes muy particular. El proyecto político y social de los enemigos durante la guerra será recurrente en algunas coyunturas políticas y conmemorativas (Sevillano, 2007), pero también a partir del proyecto político social franquista, cuando se afirma a partir de otro inexistente por haberse podido vencer. Pero el enemigo del bando contendiente se fue transformando a lo largo del tiempo tomando otras formas. Durante la Guerra Fría, el enemigo comunista es más nítido que durante la Segunda Guerra Mundial. En los momentos más críticos de la Guerra Fría, el mismo aflora en su mejor versión soviética, maoísta o castrista pero no solamente está en un bando en guerra, como ocurre con tanta frecuencia en los documentales exhibidos, sino también en los huelguistas y los que alteran el orden, como ocurrió en el mayo del 68 en Francia. Finalmente, el enemigo interior en la evolución del franquismo queda también patente mediante la exhibición de imágenes y temas muy dispares que, sin duda, son un reflejo fidelísimo de las políticas de censura del régimen.

Un enemigo común es un incomparable factor de cohesión, como se ha estudiado para el caso del judeo-masónico, tan presente y asociado al comunista en España franquista (Domínguez, 2009: 449-481).

\section{Metodología}

El NO-DO como fuente documental empezó a ser tenida en cuenta con anterioridad pero actualmente la Filmoteca Nacional en su web permite la consulta on-line desde el primer número, que data de enero de 1943 hasta el último, de mayo de 1981, si bien hay una larga 
etapa de la que no se conserva la sonoridad de algunos noticiarios. Es un período relativamente homogéneo que abarca la posguerra, en pleno racionamiento hasta el momento -tras el 23-F- la consolidación democrática o el fin de la Transición, según la cronología de la mayoría de los especialistas del Mundo Actual (Quirosa-Cheyrouze, 2007: 17).

La presentación de los noticieros por la Filmoteca Nacional, con un resumen de los contenidos de cada número, permite seleccionar determinados temas de interés. Se puede consultar el "programa de mano" -el contenido de cada noticiario-, que debió editarse incluso repartirse quizá en algunas etapas. En estos programas hay expresivas ilustraciones: una cámara de NO-DO enfoca al mundo sobre el que está a punto de posarse un águila. En el espacio central el resumen del noticiario y en los laterales, siluetas de la Torre Eiffel, el Discóbolo, el Puente de Londres, una casa oriental, la silueta de San Basilio de Moscú, el Taj Mahal, ruinas romanas, un dromedario con fondo de pirámides y un casco de guerra, entre algunos otros monumentos. Apenas sin modificaciones hasta agosto de 1964 en que se sustituye por una moderna bola del mundo y, avanzados los sesenta, por unos adornos básicos sobre fondo ocre.

Hemos visionado una mayoría de los noticiarios: todos los que tienen alguna referencia a la Guerra Civil, los que se emitieron en aniversarios del comienzo o fin de la Guerra y en fechas conmemorativas las que se solían repetir en julio y en abril por el comienzo y final de la Guerra y en noviembre, el mes que recordaban la muerte de José Antonio Primo de Rivera, pero también aquellos ofrecidos en momentos tensos de la Guerra Fría. En algunos períodos, como el que abarca desde 1946 hasta agosto de 1950 los noticiarios están sin sonido, total o parcialmente. En otros el sonido está deteriorado, en cuyos casos hemos prestado atención a las imágenes. En la web de la Filmoteca se especifica si "el audio original está deteriorado o se ha perdido" y suele ocurrir en las fracciones elaboradas en España, ya que las noticias del extranjero sí tienen sonido.

Sobre todo, de los noticiarios que se han conservado bien hemos recogido tanto los contenidos relatados como las imágenes para analizarlas, teniendo en cuenta los recursos utilizados a fin de conseguir objetivos políticos más o menos previstos a fin de observar las imágenes más destacadas y las valoraciones de los acontecimientos así como su duración.

Para citar los noticiarios pondremos entre paréntesis $\mathrm{N}$ y el número del noticiario, especificando si es la edición $\mathrm{A}, \mathrm{B}$ ó $\mathrm{C}$, porque los primeros números son únicos. A partir del vigésimo había dos de forma regular: uno A y uno, B con la misma fecha y algún cambio en su contenido. Más tarde, a partir del número 926, se añadió una versión C.

\section{El enemigo liberal}

El enemigo liberal lo era dependiendo de las coyunturas y de la complejidad de las mismas. Acabada la II Guerra Mundial, España fue condenada por su posición ante la misma y por ser una dictadura con las características de esos momentos. Si al principio había declarado su neutralidad, al observar las primeras victorias alemanas y, más tarde, la incorporación de Italia en junio de 1940, se declaró "no beligerante". Al día siguiente tropas españolas ocuparon Tánger. En noviembre de 1942 desembarcaron estadounidenses y británicos en el Norte de África y Franco temió una invasión. Así, tras la primera caída de Mussolini en julio de 1943, Franco volvió a la posición de "neutralidad" (N 59-B), decidió la vuelta de la División Azul del frente del Este y ordenó "la neutralidad informativa" (Moreno, 2006: 391).

Terminado el conflicto, España fue excluida del ordenamiento internacional. Las presiones de los exiliados, incluso del mundo socialista que habían terminado la Guerra con un enorme prestigio y el hecho de que la "guerra fría" aún no había dado todos los pasos, contribuyeron a este aislamiento que provocó en el régimen de Franco una doble estrategia en cuando a los noticiarios se refiere. Por una parte, resaltó los actos de amistad de ciertos países, aunque estos fueran pocos y de escasa talla diplomática dentro de la diplomacia inter- 
nacional y, por otra, resaltó evidenció los actos de adhesión a Franco, organizados a tal fin.

En el caso de los primeros, en los noticiarios siempre hubo un hueco para demostrar que algunos embajadores presentaban sus cartas credenciales o seguir algunas visitas de jefes de Estado o príncipes que visitaban España. Se trataba de "los países hermanos" (Rodríguez, 1999: 200) que no eran, en realidad, tantos puesto que Franco podía ofrecer al cuerpo diplomático acreditado en Madrid un almuerzo con cierta periodicidad (N 55-A). En el primer noticiario emitido en enero de 1948, justo en el mismo que se anunciaba el discurso de Marshall en el Congreso norteamericano para convencer de su ayuda en la conjura del enemigo comunista, España destacaba su amistad con Argentina (N 198-A, 211-A, 212-A y B y 213-A).

Si unos eran insignificantes, otros fueron desproporcionadamente resaltados, como el viaje de casi tres semanas que hizo Eva Duarte de Perón en junio de 1947. Se le fue llevando por las ciudades más importantes y recorrió todos los monumentos significativos, sellando una amistad con Argentina aireada por todos los medios: con pancartas de reconocimiento y aclamaciones a sus discursos. Evita era la estrella de varios noticiarios (N 233-B y 234-A). Las crónicas que aludían a la amistad de ambos países siguió por mucho tiempo, ya fuera a través de partidos de fútbol u otros hechos más trascendentes, como la entrega por parte del Ministro de Asuntos Exteriores de los restos del padre del general San Martín, que habían descansado en una iglesia de Málaga desde su muerte, al comandante del buque-escuela "La Argentina" (N 241-A). En un noticiario se pueden ver las banderas, de los países que defendieron a España en la ONU (N 261-A) entre ellas, la de Argentina que, aunque no se trataba de un país liberal como los demás, pero lo hemos incluido porque la bipolaridad del mundo situaba a este país en el mundo capitalista.

Imponentes manifestaciones patrióticas en diferentes puntos de España eran recogidos por las cámaras de NO-DO, que se detenían ante algunas pancartas: “¡España por Franco!”, "Primero, independencia; después, ya hablaremos" o "España no quiere ser gobernada por traidores" (N 207-A), se emitían en la semana del 23 de diciembre de 1946. El plebiscito de la Ley de Sucesión formaba parte de la misma estrategia de legitimación. Después de todo, España votaba, las ventanillas de los censos atendían las consultas y las personalidades políticas y personas conocidas estaban ante las urnas (N 336-B) en julio de 1947. Dos semanas después, en un noticiario escenificaba Franco la recepción de un pergamino con los resultados del referéndum, como si se acabara de enterar (N 239-A), pero poco antes otra gran manifestación coincidiendo con el décimo primer aniversario del comienzo de la Guerra Civil tuvo lugar bajo el lema "La voluntad de España" que mezcla imágenes del reciente referéndum y las de manifestaciones de adhesión a Franco "Frente a los que quisieran hacernos volver a vivir las horas de terror soviético y menoscabar nuestra soberanía inabdicable (sic)" (N236-A). Otra movilización por la soberanía de España congregaba "Medio millón de personas, que se manifiestan en Madrid contra la injerencia extranjera y vitorean al Jefe del Estado en la Plaza de Oriente. Imponente expresión de unidad nacional" (N 206-A).

El enemigo liberal dejaba de ser enemigo para pasar a ser solamente una alternativa extraña e improbable porque ambos tenían uno común más poderoso, que era el comunismo. Poco a poco, se fueron resaltando los medios modernos con que contaban los EEUU para la guerra, las pruebas nucleares, su poder en el mundo de la Tecnología y la Ciencia. Aunque aún faltaban unos años para que se firmaran los acuerdos entre España y los EEUU se estaba gestando el cambio y en diciembre de 1947 se enfatizaba la labor del "tren de la amistad" que mandaba EEUU para aliviar las necesidades de Europa (N 258-A).

Los EEUU mantenían continuos gestos de apoyo a España y, paralelamente diferentes países iban presentando cartas credenciales a través de sus embajadores en España, o enviados plenipotenciarios a fin de sellar una amistad que la propaganda franquista aprovechó para, a través de la prensa y el NO-DO, demostrar que España no estaba tan aislada. Así, las 
visitas de Abdullah de Jordania en septiembre de 1949 (N 350-A) o del presidente de Liberia (N 504-A) entre otras, eran magnificadas cuando España estaba aún fuera de la ONU.

Cartas credenciales de los embajadores durante el año 1950, de Bolivia, (N 371-A), Perú (N 368-A), Brasil (N 378-A), Egipto (N 393-A), Irlanda y El Salvador (N 406-B), Honduras (N 413-A), Nicaragua y Colombia (N 416-A), Chile (N 419-A); fueron seguidas de otros países europeos como Bélgica (N 426-A), Inglaterra (N 429-A); Italia y Dinamarca (N 432B); cuando llegaba otro embajador, como el de Brasil (N 503-A), Panamá (N 461-B); Irán y Costa Rica (N 435-B). Paralelamente los gestos de EEUU eran cada vez más evidentes: las relaciones turísticas merecieron estar en un noticiario de finales de 1951 (N 463-A); las paradas de la VI Flota Americana en puertos del levante español como Valencia (N 530-A) y Barcelona (N 420-A); recepción de una senadora norteamericana en marzo de 1955 (N 637-A), la llegada a Madrid de Mr. Heiskell, editor de la revista LIFE (N 343-B) en el verano de 1948, o la llegada de cargas de trigo procedente de EEUU para España (N 349-B). El mensaje era que España se había mantenido siempre en su sitio pero EEUU, el país más poderoso del mundo, que además enfrentaba a la URSS, se acercaba nuestro país a través del cine, los marines en las calles españolas, algunos estudiantes y periodistas interesados en la cultura y representantes institucionales.

Antes de que culminaran los acuerdos entre EEUU y España, no obstante, esta organizó una última campaña contra un "enemigo occidental". De nuevo "Gibraltar, español" se concretó en una exposición en el Palacio de Bibliotecas de Madrid, organizada por la Sociedad de Estudios Internacionales, con documentos históricos, como el texto del Tratado de Utrech y mapas relacionados con el Peñón, incluso la carta del rey de Inglaterra que prometía su devolución (N 650-A).

En las relaciones con EEUU los embajadores a su llegada eran grabados por las cámaras de NO-DO (N 117-A, 483-B, 537-A, 639A). Los años 1952 y 1953 fueron los que más noticias sobre EEUU generaron, destacando la firma de los Acuerdos de Defensa y Ayuda Económica en el palacio de Santa Cruz de Madrid (N 561-A), las visitas a las bases militares, como a la de Rota. Se destacaba que era la más importante de Europa "en el plano de la defensa común" (N 720-A), menudeando las entregas de aparatos como aviones (N 687-A), o dragaminas (N 623-A). Como consecuencia, España fue aceptada en la ONU. Para dar a conocer la noticia se publicó en los últimos días del año 1955 un largo reportaje retrospectivo, presentado con el título "La justicia reparada". Se especificaba que España protestaba desde 1946 pero tardaron nueve años en reparar aquella injusticia. "El tiempo nos dio la razón y la verdad se impuso contra todas las torpes campañas" decía el relator mientras se proyectaban manifestaciones de adhesión a Franco (N 677-A), que recibía así el mejor espaldarazo, junto a otro proveniente de la Iglesia que mantuvo siempre vigente su particular contribución. Poco antes de los acuerdos con EEUU, Franco recibía el Gran Collar de la Orden Suprema de Cristo en el mismo Palacio de Oriente, concedida por Pío XII (N 583-B).

Así, a partir de 1955 ya el enemigo era, sobre todo, el comunista. En plena Guerra Fría, el reconocimiento de España en los organismos internacionales era una realidad gracias, en buena medida, a la presión de EEUU que contaba con unas bases militares de gran valor estratégico en España. En los noticiarios se destacaron los problemas del liberalismo, como las huelgas o los movimientos sociales, muestras de la imperfección de un sistema que contrastaba con la "Paz de Franco".

\section{El enemigo huelguista}

Desde los primeros números del NO-DO la idea de orden y la reconstrucción sobre fondos asociados a "lo anterior" se concretó en constantes noticias relacionadas con el mundo del trabajo, que están elaboradas con un cuidado especial y un tratamiento propagandístico continuo. Franco visitando fábricas y dando premios a los productores, como gustaba al 
régimen llamar a los obreros y llaves de casas eran respondidas por aclamaciones fervorosas. La escenificación de dar una llave de una vivienda a una persona que hacía un gesto de sumisión al cogerla resultaba tan plástica que extendía esa emoción a quienes anhelaban una vivienda cuando eran un bien tan escaso. Y extendía también que la armonía de clases y no la lucha era el camino para conseguirlas.

Desde la primera emisión, la representación de una España en marcha se acompaña de imágenes de fábricas que funcionaban, campos que daban frutos, peces enredados en las redes de los pescadores. Los primeros minutos ya querían enseñar que cada persona tenía un papel y que la Patria dependía del conjunto de todas las contribuciones y de que todo el mundo respetara el ritmo. Durante los primeros años se enseña en los noticiarios cómo los republicanos habían destruido las fábricas y cómo Franco las había reconstruido, de tal forma que las visitas a las mismas durante las visitas de Franco y los ministros eran grabadas con gran precisión. En uno de los primeros noticiarios se explica, en apenas dos minutos: "En Sabadell las hordas marxistas en su huida destruyeron las fábricas textiles. La victoria de Franco ha permitido la reconstrucción de estos establecimientos" (N 29-A). Las imágenes del trabajo en el campo con reconfortantes y nuevas viviendas eran imágenes muy repetidas, sobre todo en las fiestas de los aniversarios de fin de la guerra.

El 18 de julio, la fecha en que el golpe de Estado contra la república vino a provocar uno de los mayores dramas de nuestra historia se convirtió en Fiesta de Exaltación del Trabajo, a fin de evitar cualquier conmemoración el 1 de mayo como fecha reivindicativa. Diversos reconocimientos y premios eran otorgados a empresas y trabajadores ejemplares. "Labor social de una fábrica" era, por ejemplo, un reportaje de Vall de Uxó que dejaba patente las ventajas de la "armonía de clases" (N 151-B y 157-B). La visita de Franco a Asturias en junio de1946 estuvo precedida de un reportaje de NO-DO titulado "Lo que no se olvida" sobre el episodio de 1934, presentado como el asalto al poder de fuerzas terroristas. Así, cuando Franco llegó a la cuenca minera y fue grabado en un alto horno de Duro Felguera como, más tarde, en los astilleros de la Naval de Levante o en los de Sagunto (N 229-A) quedaba asociado a las fábricas en funcionamiento. Franco, visitando, según proyectó el NO-DO en varias ocasiones, los talleres de la Maquinista Terrestre y Marítima, la antigua fábrica metalurgia que años antes había sido escenario de varias huelgas muy prolongadas (N 230-B), incluso imponiendo al lugar la Gran Cruz del Mérito Civil (N 518-B) en 1952 es bastante significativo, todo ello un poco antes de que la empresa suiza Brown Boveri \& Cía la destinara a taller para material eléctrico y motores para locomotoras movidas por electricidad.

Para completar el tratamiento positivo del sindicalismo vertical en tan potente medio de comunicación, varios encuentros a distintos niveles, eran presentados a la población que iba al cine como reuniones necesarias que conjuraban los conflictos en el mundo del trabajo. Las elecciones sindicales, para colmo, eran exhibidas como las verdaderamente democráticas (N 96-A).

Frente a ello, las huelgas tan prohibidas como condenadas en el nuevo relato franquista, estaban unidas al proceder de los rojos que arruinaron a España. Acabada la Segunda Guerra Mundial, las noticias de algunos conflictos sociales y, significativamente en el mundo del trabajo se exhibieron como partes del NO-DO. Coinciden, sobre todo con el período de aislamiento de España, procurando lanzar un claro mensaje según el cual los países que aislaban a España tenían serios problemas internos y evidentes conflictos sociales.

Así, desde la exteriorización del caos en Francia por la huelga convocada por los sindicatos ferroviarios en julio de 1947 (N 238-A) al hambre y las escenas de miseria presentadas en varios puntos de Europa aún a finales de ese mismo año, con huelgas de fondo, estuvieron muy presentes (N 258-B y 250-A). Las necesidades que justificaron las ayudas norteamericanas en los "trenes de la amistad" se vieron continuadas por otras noticias similares relativas a las huelgas y los disturbios que ocasionaban problemas de abastecimiento. 
Si en enero de 1948 se aseguraba que los ingleses comían pescado gracias a los envíos desde África del Sur (N 262-A), en febrero se presentaba la capital italiana "bajo las huelgas de inspiración comunista", paralizada y con una lucha en la calle que apenas las fuerzas del orden lograban aplacar (N 265-B). Así, el bloqueo de Berlín (N 291-B), "los desórdenes revolucionarios en Italia" (N 292-A) y las huelgas en las minas de carbón francesas de finales de 1948 y en los puertos de Nueva York (N 309-A) servían al régimen para poder contextualizar con éxito las necesidades en España que aún se arrastraban desde la guerra: fuera de España todo funcionaba peor.

Franco, que inauguraba la tercera etapa legislativa de las Cortes comparecía ante una clamorosa y generalizada manifestación de adhesión (N 334-B) que contrastaba con el descontrol en Alemania, donde las huelgas ferroviarias llevan a piquetes a invadir las vías de los trenes y a enfrentarse a las autoridades. Sin voz, las imágenes de los desórdenes eran suficientemente explícitas de un lugar nada edificante (N 337-B), en este caso, Berlín, pero también Tokio, prácticamente tomada por elementos subversivos (N 340-A). En una capital como París, cuando no había una huelga de transportes es porque se había organizado otra por las modistillas, haciendo una demostración de fuerza las mujeres que asistían a un mitin, como el que daba una trabajadora en noviembre de 1949 (N 357-B) y unos meses antes se presentaba una huelga de enterradores en Nueva York que había llevado a los católicos de la ciudad a hacer de esquiroles ante la falta de un servicio tan esencial (N 327-B). Hasta los gondoleros venecianos paraban cuando querían (N 448-B). El mundo exterior a merced del sindicalismo de clase lucía caótico y curioso, carente de seriedad y de proyecto de futuro.

Sería prolijo seguir la serie de ejemplos pero las noticias sobre huelgas siguieron estando presentes. Desde la exhibición de Nueva York "a media luz" a causa de una huelga del carbón (N 375-B) o en Londres, a la huelga de surtidores de gasolina en la misma ciudad, ya en 1953 (N 566-A), estos conflictos quedaban asociados a inconvenientes graves para la economía y la paz social y siempre se evitó exponerlas como estrategias obreras sino como cataclismos originados por "fuerzas oscuras". No hay que olvidar, sin embargo, que se le quitaba importancia al situar estas noticias muy breves junto a un concurso de peluquería o un recorrido por un mercadillo de un país lejano.

\section{El enemigo revolucionario}

Algunos de los conflictos sociales que tuvieron lugar en el mundo desde el final de la II Guerra Mundial fueron interpretados en el NO-DO bajo el mismo denominador: organizados por los comunistas. No obstante, al desarrollarse en países al margen del control de la URSS y China, hemos de situarlo en un nivel diferente. Podía tratarse de explosiones sociales como el "bogotazo", movimientos de carácter independentista o contra las políticas de determinados países.

En primer lugar, por la cronología, observamos algunos estallidos relacionados con las consecuencias de la II Guerra Mundial. El hambre, los desajustes de las fronteras políticas y demográficas, los refugiados y los acuerdos. Dentro del mundo capitalista, incluso en los lugares más emblemáticos podían darse casos de revueltas y manifestaciones debidas a la falta de comida que eran preocupantes y movía a EEUU a preparar un plan de ayuda, el Plan Marshall que se justificaba presentando esas crisis como un síntoma que podía degenerar en revolución (N 252-B) y mediante las acciones exhibidas de los rebeldes griegos, que mantenían al país heleno en estado de guerra (N 271-B).

Otros acontecimientos provocaban manifestaciones de indignación que eran presentadas como conatos revolucionarios en los países capitalistas (N 292-A), como cuando Togliatti, el líder comunista italiano, en julio de 1948 sufrió un atentado fascista, que dio lugar a una grave crisis política que incluyó una huelga general convocada por la Confederación General Italiana del Trabajo, los repetidos problemas en Berlín, a veces concretados en 
disturbios importantes (N 328-B y 513-A). Incluso a la propaganda del régimen fueron propicios algunos motines en prisiones estadounidenses que demostraban que ni las potencias con más medios, estaban libres de la subversión (N 488-A). De modo muy significativo se puso como reportaje un momento de los disturbios que acompañaron el Congreso del Movimiento Europeo celebrado en Bruselas en marzo de 1949, achacando a los socialistas y comunistas su promoción y consiguiente desestabilización política (N 324-B y N 397-A).

Los movimientos nacionalistas también tuvieron su lugar en los noticiarios, sin explicación de los problemas fundamentales y poniendo el acento a veces en detalles secundarios. Los disturbios producidos en la India tras su independencia fueron recurrentes, con la figura de Gandhi, como personaje pintoresco de aquellos momentos que enfrentaban a la Liga Musulmana y a los hindúes del Partido del Congreso. Las imágenes eran rápidas y el relato de los problemas coloniales nunca era claro (N 215-B y N 219-A). De la misma forma, se exhibieron las revueltas anticoloniales de Madagascar desarrolladas entre 1947 y 1948, en la zona oriental de la isla por el Movimiento Democrático para la Renovación Malgache, que se saldaron con decenas de miles de muertos. La represión sobre una población presentada como salvaje llegaba a España aunque fuera durante unos minutos (N 262-A).

Próximo Oriente, una de las regiones donde se registraron serios problemas en el mundo bipolar, era noticia por los enfrentamientos entre judíos y palestinos, ya antes de que se presentara la Resolución 181 para la división en dos Estados. La voladura del Club de Oficiales británicos en Jerusalén (N 221-B) fue seguida de otros episodios que no eran comprendidos por quienes veían estos noticiarios, donde se exponían algunas imágenes comentadas superficialmente.

Los disturbios en Suez, en la zona del canal de una población enfrentada también a las tropas británicas (N 475-A) siguió siendo noticia con la llegada de Nasser al poder y, en lo que se refiere a la evacuación del canal (N 607-A). Coincidía este punto estratégico con los primeros movimientos independentistas en el Magreb, se mostraron en NO-DO los disturbios de Túnez de febrero de 1952 (N 476-B) y Marruecos en octubre de 1952 (N 512-B).

En África negra, donde tantos movimientos se empezaron a implicar en procesos independentistas se destacó el Mau-Mau de Kenya, del que se exponían en las cámaras sus armas blancas. Casas atacadas y europeos que se defendían con armas de fuego, como se destacó en una noticia sobre dos mujeres "que hicieron frente al Mau-Mau", en definitiva, dos europeas con rifles que ahuyentaban a los indígenas, presentados en campos de concentración por las cámaras de los periodistas de entonces (N 525B).

Iberoamérica fue una región donde se registraron algunos sobresaltos muy significativos en el contexto de la Guerra Fría. De hecho, los poderosos EEUU, de los que en casi todos los noticieros se anunciaban nuevas y poderosas armas de guerra, fueron objeto de atentados sus muy protegidos presidentes: Truman (N 411-B) o Kennedy (N 1090-B). Coincidente en el tiempo con el del primero en la Casa Blanca se difundieron los disturbios de Puerto Rico donde una insurrección dirigida por el Partido Nacionalista de Puerto Rico, que proclamó la República, hasta que fue sofocada (N 411-B) y dos nacionalistas se consideraron implicados en el atentado de Truman. En Guatemala, el derrocamiento del presidente Jacobo Árbenz que había planteado reformas que afectaban a los grandes intereses económicos, tuvo lugar en junio de 1954 tras la invasión de un grupo rebelde desde Honduras dirigido por un oficial del ejército exiliado. NO-DO presentó el caso como una "lucha anticomunista" del país (N 600-A).

Una de las explosiones sociales más importantes del siglo XX tuvo tugar en la capital de Colombia tras la muerte de Jorge Eliézer Gaitán, un líder populista y antiimperialista, el 9 de abril de 1948, cuando un amplio movimiento, conocido como "Bogotazo" desencadenó durante varios días muertes y actos de destrucción en algunos puntos del país, incluida la capital. NO-DO emitió un breve reportaje en inglés que mostraba una ciudad en guerra, destacando un niño muerto y escaparates de tiendas destruidos (N 280-A). El período conocido 
como "la violencia" que sobrevino mereció otros espacios a cuenta de los disturbios de los meses siguientes (N 364-B).

Mientras, otros episodios eran silenciados, como el movimiento 26 de julio de Cuba o la masacre de Méjico de 1968. La revolución cubana mereció una breve información de la celebración de los seguidores de Castro en Madrid en el Retiro y la misa en las Descalzas Reales por lo que consideraban "el final de la guerra civil" (N 836-A).

La exhibición de una revuelta tuvo su mejor expresión en el mayo del 68 francés, que fue comentado en NO-DO a partir del día veintisiete de ese mes. Las imágenes de los estudiantes sentados en las calles, coches quemados, adoquines levantados y el añadido de la huelga general presentaban al país vecino como víctima de una alteración del orden insoportable (N 1325-B), que se vio continuada en otros noticiarios posteriores ( $\mathrm{N} 1327-\mathrm{A}$ ) en los que se describía la destrucción de la capital parisina mediante la exhibición de montones de basura y centenares de heridos. La revuelta parisina encaminándose a la normalidad fue objeto de otros noticiarios posteriores. En uno, se presentaban manifestaciones en pro y en contra de las medidas gubernamentales (N 1329-B) y, en fin, las elecciones en Francia que trajeron una mayoría gaullista que se proponía restaurar el orden (N 1331-A). Habían sido, en boca del relator de NO-DO "los peligros que amenazaban al vecino país". Después de estos momentos de emisión, desfiles "de la Victoria" en España e imágenes felices se confirmaban representativas de la disciplina y el orden de Franco.

\section{El enemigo comunista}

En la propaganda del régimen el enemigo comunista se extendía más allá de los militantes del PCE o de la misma URSS. Es sabido que podía ser tachada de comunista cualquier persona que no tuviera una adhesión nítida o bien presentara actitudes de oposición, fuera de una forma u otra. Conveniente para esta propaganda, rojos y comunistas, la mayoría de las veces, aunaban a una serie heterogénea de personas, organizaciones o instituciones.

Era inevitable que, pese a la Guerra Civil, quedaran solapados y sin apenas energías, pero exigían una vigilancia continuada. Cuando se exhibían unas casas nuevas, unas iglesias reconstruidas, unas obras públicas impresionantes lo que se mostraba era la victoria sobre el "enemigo". Cuando se reproducían los conflictos mundiales provocados por el enemigo comunista no sólo se pretendía poner en alerta a la población española de sus peligros sino también provocar una simple conclusión según la cual en España se vivía una paz que no se disfrutaba en ningún rincón del mundo.

El enemigo interior no se representa sino por sus efectos y por su contraposición, que es el régimen franquista. Los noticiarios NO-DO, perfectamente revisados antes de su exhibición, no tenían entre sus objetivos presentar al enemigo opositor. Hasta la época de la Transición en que ya empezaron a aparecer noticias relativamente abundantes de actividades y personajes que nunca hubiera permitido el régimen de Franco, el enemigo interior solamente apareció secundariamente en dos noticiarios. Uno fue emitido el 10 de enero de 1944. Eduardo Aunós, el Ministro de Justicia, pronunciaba un discurso sobre el decreto de libertad condicional que "dejaba resuelto el problema penitenciario", que iba acompañado de imágenes de la cárcel madrileña de Porlier, en la que se podían ver algunos presos políticos. Se explicaba en el relato sonoro que quedaría una población penal similar a la que había antes del 18 de julio de 1936 (N 54-A). La otra noticia era la visita al Valle de los Caídos que hizo Franco para ver las obras del monumento. Las visitas de Franco siempre acompañadas de aclamaciones y saludos con pañuelos blancos, esta vez era observada en silencio y miradas bajas por los presos que trabajaban o se paraban ante el paso de las autoridades (N 256-B).

En otro ámbito, no necesariamente relacionado con la oposición -muchos especuladores de alto nivel estaban cerca del régimen-, también quedó de manifiesto la repulsa hacia los especuladores. El franquismo que había impuesto el racionamiento y, a la vez, consentía 
a ciertas personas allegadas al régimen su enriquecimiento personal, más o menos importante, a veces echaba mano del fenómeno del mercado negro para descargar las iras de la población. En 1948 una de las manifestaciones contra los especuladores, celebrada en Madrid, atacaba a estos sectores o personajes y en las pancartas que mostraban las imágenes se podía leer: "Menos multas y más horcas" o "Caudillo, tenemos fe en tu justicia" (N 266-A).

Una de las estrategias -y la primera según la particular cronología de los noticiarios-, era la presentación de la Guerra Civil como neutralización necesaria del enemigo y la exaltación de la figura de Franco, que era exhibido como el máximo genio de tal consecución. Así, la Guerra Civil se presentaba como un acontecimiento de referencia (Rodríguez Mateos, 2005). En el noticiario primero se abrían las puertas del Palacio de El Pardo donde estaba Franco sentado escribiendo y dedicando su genio a la recomposición de España, maltrecha, según aparecían las ruinas del Alcázar de Toledo o de la Ciudad Universitaria (N-1). Cientos de documentales recordaban bien un aniversario de la liberación de una ciudad, un desfile "de la Victoria", la existencia de los "Caídos", objeto de otros tantos homenajes. Bajo el título de “¡Españoles, acordáos!” en varias ocasiones se emitieron reportajes más o menos largos sobre la Guerra. Si en algunos se presentaba el extenso enterramiento de Paracuellos: "millares de víctimas inmoladas al Moloc soviético" (N 22-A), en otros se recurría a imágenes de manifestaciones, caras iracundas y grupos armados por las calles y edificios en ruinas (N 170-A).

"Lo que no se olvida" era la Guerra, que como tal nunca era citada, sino con los eufemismos de "cruzada" o "aquellos días". Quienes estaban en el otro bando eran fuerzas terroristas que, desde 1934, se querían adueñar del poder, asaltaron, profanaron los templos y dieron armas a las masas sin ley. A esta introducción se le añadía el número de aniversario correspondiente y se exponía cómo a los siete o los diez años había concluido la miseria y la ruina (N 170-A). Las caras siniestras de los rojos disparando y portando pancartas de Stalin sincretizaban el mensaje anticomunista.

Por ello, la escenificación de la "entrega" encerraba un fuerte acto didáctico. Franco o el régimen no subían los salarios a los trabajadores a fin de que pudieran adquirir una vivienda sino que se les suministraba las llaves o, al menos, así lo teatralizaban; los edificios religiosos no habían sido reconstruidos con el esfuerzo de todos sino que Franco los ofrecía personalmente a la Iglesia, como la catedral de Santander (N 556-A); Brunete lo entregaba reconstruido (N 186-A). Lo que el enemigo había destruido el régimen lo había rescatado. NO-DO tuvo durante muchos meses una sección diaria titulada "Reconstrucción" que, más tarde, cambió por "Construcción".

Para el régimen franquista el homenaje a sus caídos era algo incuestionable y riguroso. Explica que trajeran al General Primo de Rivera a su Jerez natal (N 222-A), una vez que su propio hijo José Antonio era uno de los que tuvo más homenajes en el monasterio de El Escorial hasta que fue trasladado a Cuelgamuros. A finales de noviembre, año tras año era dedicado un reportaje a su figura y a su recuerdo (N 48). Los falangistas muertos, los combatientes de la guerra y sus familias (N 391-A), todos tenían unos reconocimientos que solo tenían sentido por la existencia del enemigo, aún capaz de nuevas maldades, que justificaba el característico en la posguerra "desigual reparto del dolor" (Langarita, 2016: 129).

En España la Guerra había terminado pero aún quedaban algunos enemigos. La guerrilla, que el régimen prefería calificar de "bandoleros" y las organizaciones clandestinas, con escasa operatividad, no obstante estaban en el punto de atención de las autoridades y era una vigilancia que trataban de extender a la población entera. Así se presentó en Madrid una manifestación de duelo de unas 300.000 personas que despedían en un excepcional entierro a "dos falangistas asesinados por el comunismo" (N 119-A). Era un atentado de la Agrupación de Guerrilleros de Madrid que asaltaron la Subdelegación de FET y de las JONS de Cuatro Caminos, aunque en el NO-DO no se decía que, como consecuencia directa, fueron fusiladas nueve personas, desorganizada la precaria organización del PCE y la imprenta de 
Mundo Obrero, ni que al día siguiente del asalto fueron fusilados en Barcelona dieciséis guerrilleros detenidos con anterioridad, en medio de una represión desmedida como reacción (Trapiello, 2001).

Más que en España, en el mundo, el enemigo comunista se manifestaba en todas las coyunturas y por todas las partes. Los primeros documentales se emitían en el contexto de la II Guerra Mundial, de tal forma que era continua la referencia a la División Azul (Garrido, 1993: 321-337). "En las heladas tierras de Rusia consiguen glorias para la Patria" se relataba en el primer noticiario emitido, en el que veía que las mujeres falangistas confeccionaban paquetes para los divisionarios (N 1). En otros se registraban visitas, como la del general Martínez Campos al frente del Este (N 28-A) o se comentan las estrategias conjuntas con el mando alemán (N 31-A). La exhibición de la fosa de Katyn era suficientemente explícita para provocar el rechazo unánime a los soviéticos, presentados como sus causantes, pese a lo controvertido de la autoría. Los espectadores podían ver durante un poco de más tiempo que en otros noticiarios los restos amontonados de centenares de personas, algunos de los cuales eran trasladados, quizá, para su inhumación (N 22) y esto en un país como España también lleno de fosas con restos de personas ejecutadas por el régimen que, precisamente no querían que los españoles se olvidaran de "estos militares polacos asesinados por la policía secreta soviética".

Si había un enemigo implacable, inductor de todos los males, ese era la URSS. Cuando comenzó a emitirse el NO-DO estaba concluyendo la batalla de Stalingrado, que marcó el principio del fin del poderío alemán. En el noticiario, con grabaciones hechas por los alemanes se emitían noticias felices de la retaguardia alemana (N 2) y otras, tergiversadas del frente, como lo bien que los nazis reconstruyen los puentes en Polonia (N 2), cómo restauraban los templos destruidos por los comunistas (N 8), o ponían en marcha una fábrica de pan destruida por los bolcheviques en Ucrania (N 13). Uno de los primeros noticiarios era sobre niños españoles "salvados de la URSS", en el que se afirma que los chicos habían alcanzado las líneas de los alemanes (N 3). "Lucha contra el comunismo" era el título de las partes emitidas que versaban sobre la II Guerra Mundial. Los tesoros de la Iglesia, en peligro por los soviéticos, eran salvados por los nazis y cuando éstos ocupaban una localidad era "La liberación de las poblaciones", justo en el momento en que las fuerzas norteamericanas cruzan la línea Sigfrido (N 102-B). Los reportajes que se refieren al frente soviético van desde el número 50 al 102. Pese a que desde febrero de 1944 se anuncia que España tiene una postura de neutralidad estricta, aún se exhiben de forma épica los aviones soviéticos derribados (N 105-B); la lucha en el frente occidental era "vista desde las líneas alemanas" (N 112-A) y ya, muy cerca del final, cuando los aliados entraron en Colonia aún se destacaba la valentía de los alemanes en el frente del Este (N 118-B). Hasta principios de noviembre de 1945 las bondades de los nazis habían sido una constante, pero a partir de ahí (N 148-A) el juicio de Nurenberg cuestionaba esa actitud destacada en los noticiarios.

Tras la II Guerra Mundial, otros conflictos de la "guerra fría" mantuvieron la alerta ante el enemigo comunista, ya fuera en Berlín, Corea, Vietnam o Cuba. El primer conflicto importante de la Guerra Fría se centró en la que había sido capital de la Alemania nazi. Los acuerdos interaliados habían estipulado que Berlín y Alemania fueran ocupadas por las tropas aliadas. Si en Yalta se habían atribuido las zonas según el avance aliado sobre Alemania pero considerando a Francia con derecho a una zona, en Potsdam se ratificó la partición y la URSS se atribuyó la competencia de abastecer Berlín, que quedaba bajo su zona de ocupación. Sin embargo, los aliados tenían otros planes. Mediante los Acuerdos de Londres (abril-junio de 1948) en las zonas de los occidentales pretendían un proceso constituyente e introdujeron una nueva moneda en Berlín. La reacción de la URSS fue el bloqueo de las comunicaciones de la zona occidental de la ciudad con la zona occidental alemana. Occidente estableció un puente aéreo para abastecer la zona occidental de Berlín y todas las imágenes que exhibió NO-DO tienen que ver con el abastecimiento como en, al menos, cinco noti- 
ciarios. Los dos primeros no tienen relato sino música y se ven aviones descargando cajas o sacos (N 290-A y 291-B). El tercero sí es sonoro, con relato y en él se asegura la amenaza que supone la URSS para la paz mundial, concretamente para la zona occidental de Berlín (N 300-B). Las emisiones sobre el bloqueo a partir de diciembre de 1948 ya presentan un paisaje de fábricas funcionando, líneas eléctricas reconstruidas (N 311-B) y, en fin, el desembarco en el aeropuerto número 100.000 junto a un mensaje de Truman al Congreso de EEUU (N 317-A).

La Guerra de Corea mereció la atención de decenas de noticiarios, como si llenaran el vacío de los espacios dejados por la II Guerra Mundial. Precisamente, una de las consecuencias de este conflicto fue la división de varios Estados: Corea había sido dividida en dos países: al norte, una república popular y en el sur una dictadura apoyada por los EEUU. Desde el triunfo maoísta en China, en octubre de 1949, se había alterado el anterior equilibrio en Asia (N 321-A hasta el 357-B). Como las tropas del Norte avanzaron hacia el Sur, Washington consiguió permiso de la ONU para encabezar un ejército, al mando de McArthur, que contraatacó. Una vuelta a la situación inicial en junio de 1953 llevó al armisticio que estableció de nuevo la demarcación del paralelo $38^{\circ}$, no sin antes costar la vida a varios millones de personas. La insistencia en el hostigamiento desde Moscú (N 396-A hasta el N 416-B), la retirada de los aliados al sur del paralelo $38^{\circ}$ (N 416-A) y hasta el agasajo a los huérfanos con regalos navideños, ya acabada la guerra (N 575-B), junto a otras anécdotas protagonizadas por niños acapararon los comentarios de otros noticiarios de esos años. El título de un noticiario da idea de la frivolidad de los comentarios sobre una guerra tan dramática: "Llegaron las lluvias. Los soldados se divierten sobre el barro" (N 503-A)". En el mismo también se recrean instantáneas sobre elecciones en Corea del Sur, como una exhibición democrática que estaba a punto de elegir a Syngman Rhee. Ese noticiario emitido el 25 de agosto de 1952 era seguido por unas imágenes de inauguración de casas protegidas para pescadores andaluces.

El conflicto de la Guerra Fría más dilatado se desarrolló en Vietnam desde 1959 a 1975. Dividido el territorio - esta vez por el paralelo $17^{\circ}$ - hasta la ocupación de Saigón por parte de Vietnam del Norte en 1975, numerosos noticiarios se refirieron a esta guerra. Ya antes, los nacionalistas vietnamitas venían luchando contra los franceses (N 216-A hasta el N 225-B), para estar presente con cierta continuidad, siempre denunciando la ayuda de los soviéticos a los del Norte (N 574-A). El fin de la guerra no mereció ningún comentario, ni en los dos meses siguientes. Ganaban terreno los reportajes deportivos, elecciones de "Majas", exposiciones de botijos y ferias diversas sobre los episodios bélicos y de carácter político.

No obstante, la "Crisis de los misiles" en Cuba, a finales de 1962 acaparó la atención de todos los medios de comunicación y la de varios noticiarios con títulos como "Conflicto cubano. A las puertas de la guerra atómica", "Bloqueo en el Caribe" o "Alarma en La Habana”. En ellos (N 1035-A hasta el 1040-B) se concretó la evolución del proceso a través del que se descubrieron dispositivos "defensivos dispuestos a entrar en acción” y, finalmente, la retirada de los mismos, pasando por una alerta en Guantánamo (N 1038-B). Se aseguraba que Cuba estaba fortificada pero en su interior "crece el caos que los dirigentes rojos tratan de remediar con manifestaciones ruidosas y bullangueras" ( $\mathrm{N} 1035-\mathrm{B})$ hasta que, por fin, ocho buques retiraban las armas (N 1038-A). La interpretación que se hizo de esta crisis no deja de ser curiosa. Los soviéticos eran partidarios de la retirada de los misiles de la isla, pero era Fidel Castro el que se negaba. Fue necesario -según el relato del NO-DO- un mes, tras "misteriosas conversaciones" para que los soviéticos lograran convencerlo.

Las intervenciones del Pacto de Varsovia en Hungría en 1956 y en Praga (Checoslovaquia) en 1968 acapararon igualmente la atención mundial a la vez que conmocionaron a los partidos comunistas en occidente que, en algunos casos, sufrieron escisiones y conflictos internos. NO-DO presentó ambas como acciones dictatoriales de la URSS sobre países mantenidos bajo un régimen de esclavitud. En el caso de Budapest, entre las últimas semanas 
de octubre y la primera de noviembre de 1956 se produjo la intervención que el noticiario interpretaba como "El sacrificio de Hungría" (N 723-B) Las imágenes que ilustraban las pantallas de cine a partir del 12 de noviembre eran las de las manifestaciones de oposición tanto en Hungría como en otras ciudades europeas y del entierro de estudiantes y obreros asesinados "por el yugo soviético". Por su parte, la intervención del 20 de agosto de 1968 en Praga supuso otra convulsión, tanto en los países occidentales como en los socialistas. Un reportaje sobre el Museo de los Relojes de Moravia, una de las tres regiones checoslovacas, se asociaba a la situación política: hasta entonces, "en Checoslovaquia había paz", luego venían las imágenes retrospectivas del ascenso de Dubcek y Svoboda, con sus programas reformistas, inaceptables para la URSS: "Los checos siguen reducidos a la condición de servidumbre" (N 1339-A). Las denuncias eran, sobre todo, hechas por los que huían por Alemania Occidental (N 1339-B).

Al margen de los conflictos de la Guerra Fría concretos, el clima general de tensión fue objeto de comentario en NO-DO en diferentes ocasiones. Los simulacros defensivos contra supuestos ataques aéreos estaban a la orden del día, ya fuera en EEUU con "Ejercicios de defensa pasiva en Nueva York" (N 467-A); o en Inglaterra "Simulacros defensivos contra ataques aéreos nocturnos" (N 489-B). Por otra parte, la llegada de evadidos a Occidente que comentaban el infierno rojo también estuvo presente a lo largo de los años: "Mikolajczk en Londres, evadido de la opresión soviética en Polonia" (N 257-B), "Llegan a San Francisco numerosos rusos blancos" (N 416-A) o "La opresión soviética en Varsovia. El ansia de liberación de los patriotas" (N 722-A). Junto a estos reportajes otros planteamientos más generales, como "La tragedia que representaría un ensayo comunista" (N 513-A).

Otro momento tenso de la Guerra Fría fue el levantamiento del muro en Berlín en el verano de 1961. En la semana del 21 de agosto se expuso un noticiario en el que se podía ver las personas que buscaban asilo en la parte occidental, que cifraban en 12.000. El recurso repetido del detalle cómico no faltó: "Hasta el gato quiere pasarse", como tampoco el contraste de las dos zonas de Berlín para concluir que "...El Berlín de los soviets está en estado de suciedad y abandono frente al esplendor y la alegría del otro. Las gentes viven tranquilas y felices mientras que, a pocos metros, viven sin garantía y sin libertad" (N 972A). Las imágenes eran de personas vestidas de gala en un baile, al que iban normalmente, según el relato de NO-DO, los berlineses tras el trabajo. El maniqueísmo siempre presente y el lenguaje superficial seguía siendo el mismo que casi veinte años antes. Sin embargo, otros episodios posteriores, de los años setenta relacionados con avances del mundo socialista o soviético no fueron emitidos ni comentados. La forma de reportaje de revista cultural y de curiosidades, había ganado terreno.

\section{Conclusiones}

El conjunto de los noticiarios emitidos desde 1943 hasta 1981 constituye una fuente documental de gran interés para el conocimiento de la propaganda del régimen y de sus representaciones del enemigo político, que ofrece diferentes caras y matices. Los exhibidos durante el franquismo tienen más reportajes abiertamente políticos y, dentro de este período, los primeros años con especial proliferación. Durante la Transición se evitan en lo posible reportajes con personajes políticos, desfiles y conmemoraciones. La campaña de despolitización y desmovilización y el objetivo de que el conjunto de la sociedad trivializara la política tiene un claro apoyo por parte del NO-DO, que ya había mutado a su forma de revista y que había entrado en una crisis sin retorno.

El enemigo presentado en el NO-DO tuvo un carácter propagandístico en una sociedad en la que el analfabetismo era muy alto, pero iba atenuándose a medida que pasaban los años. En los primeros, las alusiones al enemigo "rojo" fueron más frecuentes, así como a la Guerra Civil misma, cuyos objetivos nunca se escondieron, como los caídos de sus filas, 
que nunca se olvidaron. La oportunidad ofrecida por la II Guerra Mundial para remachar la necesidad de "la lucha contra el comunismo" duró poco menos de dos años, pero fueron justo los más duros como consecuencia del racionamiento y también de la represión sobre la oposición.

La Guerra Fría vino después, por una parte a dibujar el contexto propicio para el mantenimiento de un anticomunismo continuado, acorde con otros países occidentales. El aislamiento a que fue sometida España hasta los primeros años cincuenta se solventó sobre la marcha magnificando los actos de amistad con los escasos países amigos, pero también destacando, sin exageraciones que hubieran podido volverse en su contra, las huelgas y los desórdenes en los países occidentales, como producto de sus propias contradicciones y de una falta de definición que a España le sobraba. El "enemigo liberal" pues, lo fue sobre todo, en los finales años cuarenta aunque ciertos rasgos fueron considerados extraños a lo español desde el principio hasta el final.

En NO-DO se pudieron ver algunas imágenes de conflictos sociales, manifestaciones y guerras, pero eran tan breves que no permitían una mínima concentración de la atención sobre ellas y, casi siempre, escogidas con cuidado de no llegar a ser de interés para la reflexión o la emulación. Los mensajes sonoros trivializaban los momentos más dramáticos, adjuntando segundos más tarde noticias tan superficiales como inesperadas. Los responsables de NO-DO nunca escondieron sus intenciones propagandísticas pero, con el tiempo, no pudieron mantener la competencia informativa de la televisión ni la respuesta a los cambios sociales y culturales de España. Si en los primeros noticiarios el comunismo tenía una única asociación al crimen y las fuerzas ocultas, en los últimos podían ofrecerse partes de representaciones de los ballets soviéticos o imágenes de los barcos rusos en los puertos españoles aunque como una curiosidad de los nuevos tiempos, sin que quiera decir que NO-DO no contribuyera a afianzar un modelo de Transición conservador y sin sobresaltos.

\section{Bibliografía}

ABELLA, Rafael y CARDONA, Gabriel (2008). Los años del NO-DO. El mundo entero al alcance de todos los españoles. Barcelona: Destino.

ARDÁNAZ, Natalia (1998). "La Transición política española en el cine (1973-1982)”. Comunicación y Sociedad, vol. XI, 2, 153-175.

DE MARCO, Jynette (2013). "Los NO-Dos en la historia española del siglo XX: el caso de Cataluña”. Senior Theses, Trinity College, Hartford, CT recuperado en Trinity College Digital Repository, http: // digitalrepository.trincoll.edu/these/229.

DOMÍNGUEZ ARRIBAS, Javier (2009). El enemigo judeo-masónico en la propaganda franquista, 1936-1945. Madrid: Marcial Pons.

GARCÍA GONZÁLEZ, Gloria (2015). "Y Castilla se hizo España. Nacionalización y representación cinematográfica de Castilla en el NO-DO”. Studia Historica, 33, 253-271.

GARRIDO, Francisca (1993). "El frente del Este en el NO-DO: desinformación y propaganda, 19431945". Filmhistoria, Vol. III, n ${ }^{\circ} 1-2,321-337$.

GIL GASCÓN, Fátima y GÓMEZ GARCÍA, Salvador (2014). "El uso propagandístico de la mujer nacional durante la Guerra Civil: Noticiario español (1938-1939) “. Comunicación, 4 (1), 149-171.

LANGARITA, Estefanía (2016). "Viudas eternas, vestales de la Patria. El "luto nacional” femenino como agente cohesionador de la España franquista “. Ayer, 103,125-145.

PAZ, María Antonia y CORONADO, Carlota (2005). "Mujer y formación profesional durante el franquismo NO-DO, 1943-1975", Pandora. Revue d'etudes hispaniques, 5, 133-145.

QUIROSA-CHEYROUZE Y MUÑOZ, Rafael (Coord.) (2007). Historia de la Transición en España. Los inicios del proceso democratizador. Madrid: Biblioteca Nueva.

RODRÍGUEZ, Saturnino (1999). El NO-DO, catecismo social de una época. Madrid: Editorial Complutense. 
RODRÍGUEZ MATEOS, Araceli (2008). Un franquismo de cine. La imagen política del Régimen en el noticiario NO-DO (1943-1959). Madrid: Rialp.

ROLL GRANDE, Manuel (2001). "La provincia de Jaén en los documentales del NO-DO (19431981)", Códice. Revista de Investigación Histórica y Archivística, 24, 85-90.

SÁNCHEZ-BIOSCA, Vicente y TRANCHE, Rafael R. (1993). "NO-DO: El tiempo y la memoria”, Cuadernos de la Filmoteca, 1.

SEVILLANO, Francisco (2007). La representación del enemigo en la guerra civil. Madrid: Alianza. Recurso en Internet de NO-DO: http: //www.rtve.es/filmoteca/no-do.

\section{3}

